June 1993

\title{
USER-PRODUCER INTERACTION, LEARNING AND COMPARATIVE ADVANTAGE
}

\author{
by Jan Fagerberg ${ }^{1}$ \\ Norwegian Institute for International Affairs \\ POB 8159 DEP \\ 0033 Oslo \\ Norway
}

\begin{abstract}
Michael Porter's book "The Competitive Advantage of Nations" (1990) has led to increasing attention on the favourable impact that "advanced domestic users" may have on competitiveness. This paper presents a critical appraisal of the theoretical and empirical evidence on this relationship. An econometric test of the hypothesis - of a positive impact of advanced domestic users on competitiveness - on data for 16 OECD countries between 1965 and 1987 is presented. In general, the results give strong support to the hypothesis under test. The relationship appears to be stronger in cases where the home-market is exposed to international competition.
\end{abstract}

\section{Introduction}

Michael Porter's book "The Competitive Advantage of Nations" (1990) has led to increasing attention on the favourable impact that the domestic market, through "advanced domestic users", may have on the international competitiveness of a country. The idea that the domestic

1 This paper builds on and extends earlier work by the author on the same subject (Fagerberg 1992 a,b). An earlier version was presented at the conference "Technology Collaboration: Networks, Institutions and States", Manchester, April 21-23, 1993. The ideas owe much to discussions with members of the IKE group at the University of Aalborg, especially Esben Sloth Andersen and Bent Dalum. Furthermore, I want to thank Bent Dalum and Vibeke Jakobsen, both at the University of Aalborg, for assistance in data work. The final version has also benefited from comments from Daniele Archibugi, University of Cambridge, and two anonymous referees. Financial support from the Nordic Economic Research Council is gratefully acknowledged. 
market may affect competitiveness positively, is by no means a new one, it dates back at least to List (1841). However, neoclassical trade theorists have normally regarded it as "theoretically unsound" and as a cover for protectionism. This paper presents a critical appraisal of the theoretical and empirical evidence on this hypothesis. Based on an empirical method initially developed by Andersen et al. (1981), the hypothesis - of a positive impact of the domestic market on the competitiveness of a country - is tested on data for 16 OECD countries between 1965 and 1987.

\section{Why should "advanced domestic users" matter?}

Traditionally, most attempts to explain the specialization patterns of countries in international trade have focused on supply conditions. According to standard neoclassical theory of international trade, countries ought to specialize in areas of production that make intensive use of factors of production, with which the country is relatively well equipped. In spite of the dominant role played by traditional neoclassical theory in this area, there has always been a strand of thought that has emphasized learning as a potential source of comparative advantage. This tradition ${ }^{2}$ points to the potential effects of relations between firms or sectors, within the domestic economy, on innovation and learning, and the impact of this on the international competitiveness of the country and its specialization pattern in international trade.

The first systematic attempt to discuss the implications of these ideas for trade theory was made by Linder (1961). His argument runs as follows. First, a need that cannot be sufficiently satisfied by existing products arises on the demand side. Since entrepreneurs for various reasons (culture, language, proximity) tend to be better informed about developments in the home market than in markets elsewhere, they will usually be the first to react to the demand for new or improved products arising in the domestic market. The outcome of this activity, i.e., the innovation, then enters a period of testing and revision in which the home market is assumed to play a critical role. If the new product makes a success at home, it will probably be introduced on the export market too. Thus, in the case of developed countries, he suggested that it is demand-induced innovation within each country, not supply factors, that determines comparative advantage.

Recently, Porter (1990) has presented an evolutionary scheme of economic development based

${ }^{2}$ Writers who have emphasized the importance of relations between firms or sectors, within the domestic economy, for industrialization, growth and competitiveness include Perroux (1955), Hirschman (1958), Linder (1961) and Dahmén (1970). For an overview, see Dosi and Soete (1988). 
on similar ideas. Echoing Linder, he argues that traditional supply factors, although important in the earlier stages of development, are not among the prime determinants of "competitive advantage" in more advanced countries, where growth is assumed to be innovation-driven. The most competitive industries in an advanced country, he argues, tend to be highly integrated ("clustered"), both vertically and horizontally, with favourable consequences for learning, innovation and "competitive advantage". In Porter's scheme, this typically starts with integration between customers in traditional industries and suppliers of machinery and other types of advanced equipment, then widens through spill-overs and feed-backs to and from related and supporting industries (Porter, 1990, p. 554-5).

In this paper, we will focus on the first of these two mechanisms, emphasized by both Linder and Porter, i.e., that a high degree of integration between customers and suppliers (or users and producers) may affect international competitiveness/comparative advantage positively. This hypothesis is intuitively appealing, and there is, as shown by Porter (1990), a large amount of descriptive evidence that can be used in its defence. However, in spite of the growing popularity of this approach, many still probably feel that it is a phenomenon in search of a theory. We will briefly sketch a possible framework for the analysis.

Let us assume that the development of new technology in many cases requires close communication and interaction between users and producers of technology (Lundvall, 1985,1988). To achieve this end, a channel - and a common code - of communication must exist. The establishment of channels and codes of communication involves fixed costs, and this implies that in a stable user-producer relationship, the cost per transaction is decreasing. This is clearly an argument for keeping relationships stable. Furthermore, lower transaction costs are likely to lead to a higher volume of transactions. Hence, a higher rate of innovation should be expected in a market characterized by enduring user-producer relationships, compared to a more "atomistic" market structure. To the extent that the parties of a stable user-producer relationship can prevent the (immediate) diffusion to others of the innovations they make, as seems likely, ${ }^{3}$ they may (for some time at least) keep the benefits for themselves. Indeed, the fact that the relationship is of an enduring character, and is recognized as such by both parties, may significantly increase the probability of appropriating the benefits. Thus, a stable user-producer relationship may be interpreted as an institution that reduces the costs - and increases the pace of innovation and learning, while at the same time making it easier to appropriate the economic

\footnotetext{
${ }^{3}$ Several factors may contribute to this. New knowledge may be very specific and difficult to transfer ("tacit knowledge"). Secrecy and legal procedures (patents and trade marks) are other means.
} 
benefits. ${ }^{4}$ As a result, the competitive positions of the participating firms are likely to improve. To some extent, this holds for both users and producers, but in this paper we will focus mainly on the latter.

However, the importance of stable relationships may vary across industries. It should be expected to be of special importance in industries characterized by complex and user-specific technology. In these cases, the need for close communication and interaction between users and producers of technology is likely to be large, and the costs of establishing new relationships of this kind high. In other cases, products and technologies may be highly standardized: both transaction costs and the need for enduring user-producer relationships will be low.

To the extent that this type of interaction takes place mainly within country borders, this should be expected to affect patterns of export specialization (or comparative advantage) of countries as well. Since, as pointed out by both Linder and Porter, the costs associated with communication and interaction increase with distance and differences in culture, language, institutional settings etc., this may be a reasonable assumption to make. Porter even holds that the importance of the domestic market for competitive advantage is growing.

"While globalization of competition might appear to make the nation less important, instead it seems to make it more so. With fewer impediments to trade to shelter uncompetitive domestic firms and industries, the home nation takes on growing significance because it is the source of the skills and technology that underpin competitive advantage" (Porter, 1990, p. 19).

However, it may also be argued that the increasing role of multinationals in world production has reduced the costs of communication and interaction significantly, and that the Linder-Porter hypothesis therefore was more relevant in the past than it is presently. The empirical evidence presented in this paper may shed some light on this controversy.

Another issue raised by Porter is to what extent a competitive market structure is a necessary condition for a positive impact of user-producer interaction on competitiveness. He argues that "favourable demand conditions (..) will not lead to competitive advantage unless the state of rivalry is sufficient to cause firms to respond to them" (ibid, p. 72). Porter seems to be most

4 This way of looking at things shows some similarity with parts of the "new-growth" literature (see Verspagen, 1992 for an overview). However, this literature (Romer, 1986 and others), as well as the older literature in this area (Arrow 1962, Kaldor and Mirrlees 1962), discusses externalities of activities internal to firms (investment and/or production). This paper focuses on the effects interaction between different firms. 
concerned with competition among producers (suppliers) of technology. ${ }^{5}$ However, a similar argument holds for the user side: Users that are under continuous pressure to improve their performance, are more likely than others to demand improvements from their suppliers. Here, Porter especially emphasizes the importance of international competition:

"One competitive industry helps to create another in a mutually reinforcing process. Such an industry is often the most sophisticated buyer of the products and services it depends on. Its presence in a nation becomes important to developing competitive advantage in supplier industries." (ibid, p. 149)

\section{Data and methods}

The hypothesis that we want to test is the following:

\section{There is a positive relationship between the existence of advanced, domestic users and the competitiveness of domestic producers that supply these users with advanced equipment.}

Most empirical work in this area is descriptive (case studies). These studies are often interesting and perceptive, but it is of course difficult to know how representative they are. To allow more general statements on the empirical relationships, we have, following Andersen et al.(1981), chosen a different method. The essence of this is the use of trade statistics to measure both the competitiveness of the producers of technology and how advanced the domestic users are. It is argued that one may approximate "advanced domestic users" with "internationally competitive (domestic) users". This does not seem unreasonable. Firms that compete favourably on the world market, and want to continue to do so, have a clear incentive to acquire superior technology. This is also consistent with Porter's view (see the previous section).

A problem with this interpretation is that it limits the investigation to export products and home market sectors where the trade statistics allow a link to be made. Equipment that is used in many sectors, and sectors that mainly make use of such equipment, cannot be included. For instance, some well known "high-tech" industries, most notably the computer industry, had to be left out of the investigation for this reason. ${ }^{6}$ This, of course, does not mean that user-producer

\footnotetext{
${ }^{5}$ Porter especially emphasizes the importance of domestic rivalry, but acknowledges that, for small open economies, foreign competitors may serve a similar function (ibid, p. 121).

${ }^{6}$ Other important "high-tech" industries, such as telecommunications and pharmaceuticals, were included as "export products" but not as "home market sectors".
} 
interaction is unimportant in these cases, just that these links can not be explored by the methodology adopted here. Another consequence is that users in the service sectors of the economy (not covered by the trade statistics) are excluded. To remedy this somewhat, an attempt was made to construct special "home-market indexes" for three important service sectors. These sectors are health care, telecommunications and shipping (two of which are dominated by public-sector services).

Table 1 lists the 23 pairs of export products and home-market sectors. The sample includes all "advanced" ${ }^{7}$ export products for which the commodity classification (SITC, Revision 1, fourdigit level) allowed a link to a home-market sector to be made. The 23 pairs were divided into 5 groups, depending on the character of the home market. The first group includes export products with users in the food-producing sector, mostly agriculture. These user-sectors are strongly regulated in all countries. As a consequence, there is in most cases little competition. The second and third groups include export products with users in the manufacturing sector, in "traditional manufacturing" and "transport equipment" respectively, for which the degree of competition is generally high. The services group is divided in two: shipping and public sector services. Shipping is a typical global industry (Porter, 1990), with very competitive markets. Public sector services, ${ }^{8}$ in contrast, have until recently been strongly regulated in all countries, with little competition domestically as well as internationally.

To measure competitiveness, we use the familiar index for revealed comparative advantage (Balassa, 1965). For a particular country and product, this index is the ratio between the market share of the country on the world market for this particular product and the market share of the country on the world market for all products. Letting $X$ denote exports, $i$ the exporting country and $j$ the export product, the index for revealed comparative advantage $(S)$ for country $i$ in product $j$ can be presented as follows:

(1)

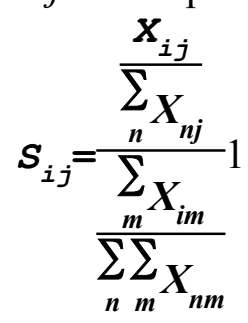

7 "Advanced" is used here in a broad sense. Only products based on natural resources and relatively unsophisticated ("mature") manufactures were excluded.

8 As follows from table 1, we have assumed that the health sector is the "user" of pharmaceutical products, although strictly speaking the final users are the individual patients/consumers. However, it is the health sector that decides on standards etc., which is what matters in the present context. 
where $\mathrm{n}=1, \ldots, \mathrm{i}, \ldots, \mathrm{N}$, and $\mathrm{m}=1, \ldots, \mathrm{j}, \ldots \mathrm{M}$.

This index has the property that the weighted mean is identical to unity for each country across all commodity groups, and for each commodity group across all countries. Thus, a country is said to have a revealed comparative advantage (be specialized) in a product if the RCA index exceeds unity.

It was argued above that one may approximate "advanced domestic users" with "internationally competitive (domestic) users". Thus, RCA indexes were calculated also for the (k) home-market sectors ("home-market indexes", $S_{i k}$ ). The indexes for the service sectors were constructed to make them comparable to the RCA index. For instance, if the index for a specific country for shipping exceeds unity, this implies that the market share of the country for shipping services (merchant fleet registered in the country) exceeds the market share of the country for goods and services in general. For telecommunication and health services, which, until recently at least, were not traded on the world market to the same extent, the population of the country was used as a deflator. Thus, in these cases, a value larger than one implies that the per capita "quality" of these services in the country is higher than the OECD average. For telecommunication we used data for the number of telephone lines in the country, for health services we equated "quality" with the economic resources devoted to this purpose. A problem with the latter may be that possible differences in health sector efficiency across countries are not accounted for. For details and sources, the reader is referred to the appendix.

The trade data used in this paper were collected from OECD Trade Series C, using the IKE Data Base at the University of Aalborg. Three years were included; 1965, 1973 and 1987. Since the theory is only expected to hold for developed countries, we excluded the industrially less developed of the OECD countries. ${ }^{9}$ The countries included in the sample were: Canada, the USA, Japan, Austria, Belgium, Denmark, Finland, France, Germany, Italy, the Netherlands, Norway, Spain, Sweden, Switzerland and the UK.

\section{Testing the hypothesis}

In a general form, the model to be tested is the following:

${ }^{9}$ Australia and New Zealand were excluded due to lack of data for some of the years covered by the investigation. 
(2) $S_{i j}^{t}=f\left(S_{i k}^{t}, C_{i}^{t}\right), d S_{i j}^{t} / d S_{i k}^{t}>02$

This model includes two independent variables, the home-market index $\mathrm{S}_{\mathrm{ik}}$ and a countryspecific variable $\mathrm{C}_{\mathrm{i}}$. The inclusion of the latter reflects the possibility that there may exist additional, country-specific factors that affect comparative advantage, and which should be taken into account to avoid biased results. ${ }^{10}$ For instance, a country with a comparative advantage in natural-resource based products (SITC 0-4), will by definition not have a comparative advantage for manufactured products (SITC 5-9). Since the dependent variable in all 23 cases belongs to the manufactured group, this implies that the dependent variable may be biased against countries specializing in natural-resource based products. The inclusion of a country specific constant term may correct for this type of bias.

In principle, the choice of functional form should be based on theory. But, as is common in testing of hypotheses, we have in this case no particular theoretical reasons for preferring one specific functional form. However, to get a better approximation to the assumption of normally distributed variables, a logarithmic form is preferred. ${ }^{11}$ A Box-Cox test of functional form came up with the same suggestion. Since there were zeros in the data matrix, we had to add a small positive number to all observations to allow the transformation to be made.

Thus, the tested model is as follows:

(3) $\log \left(S_{i j}^{t}+0.1\right)=c_{i}+a \log \left(S_{i k}^{t}+0.1\right) 3$

When in the following we refer to the variables $S_{i j}$ and $S_{i k}$, it should be understood that these are in log-form, as in equation (3).

The questions we want to ask are:

1) Is there a positive relationship between the two specialization indexes, as argued by Linder and Porter, i.e. is the coefficient $a$ positive?

\footnotetext{
${ }^{10}$ This is the so called "least-squares dummy variables method" (LSDV), which is developed for use in pooled data sets. For details, see Johnston (1984).

${ }^{11}$ The index of revealed comparative advantage (S) has a skew distribution, with a long tail to the right. This creates problems in regression analysis, because it violates the assumption of normality. A logarithmic transformation of the data reduced this problem significantly.
} 
2) Does the impact of the home-market variable $\left(S_{i k}\right)$ decline over time, i.e., is the coefficient $a$ less significant in 1987 than in earlier years?

3) To what extent does the introduction of a time-lag for the home-market variable $\left(S_{i k}\right)$ improve the explanatory power of the model?

4) Are there significant differences across countries, or home markets, in the impact of the home-market variable $\left(S_{i k}\right)$ ?

To answer the first two questions, equation 3 was tested on data for 1965, 1973 and 1987, with and without the country-specific variable $C_{i}$. The results are reported in table 2 . In all cases, the coefficient $a$ turned up significantly larger than zero at the 1\% level, as the Linder-Porter hypothesis would predict. The numerical estimate of $a$ was remarkably stable across both time and differences in specification (the estimate varied between 0.43 and 0.49 ). Furthermore, there was no tendency towards a decrease in the numerical value of the estimate for $a$ or its significance. The only notable difference between the tests reported in table 2 relates to the impact of the country-specific variable $C_{i}$. In all cases the inclusion of this variable significantly increased the explanatory power of the model, but less so in 1987 than for earlier years, indicating that the importance of the country-specific factors may be reduced somewhat during this period.

Patterns of comparative advantage may be viewed as the result a of long-term historical process. Thus, there may be rather long lags present in the impact of user-producer interaction on comparative advantages. To shed some light on this issue we have included in table 3 some tests where the independent variable is lagged one or two periods. Given that patterns of comparative advantage change only slowly, the home-market variables should be expected to be strongly correlated across years, which was indeed the case. To avoid multicollinearity in cases where two annual observations of $S_{i k}$ were to be included, we had to put one of them in first differences (equations 3.2 and 3.4).

The results of the tests with lagged variables in table 3 should be compared to the result without lags in table 2 (equation 2.6). Then it becomes clear that the explanatory power of the instantaneous relationship (equation 2.6.) is not inferior to any of the lagged relationships, when adjustments for differences in degrees of freedoms are made. Thus, surprisingly perhaps, there is not strong support in the data for long lags. This is also confirmed by the low weights given to the lagged independent variables in equations 3.2 and 3.4. ${ }^{12}$ These findings may indicate a two-

${ }^{12}$ In equation 3.2, the implicit weight is 0.16 for $\mathrm{S}_{\mathrm{ik} 65}$ and 0.34 for $\mathrm{S}_{\mathrm{ik} 87}$, while in equation 3.4, 
way relationship between "users" and "producers", e.g. that the competitiveness of both parties are affected. As noted in section 2 of this paper, this would not be inconsistent with the theory, but we will not discuss this issue further here. No attempt was made to test for the direction of causality.

In the tests reported so far we have implicitly assumed that all countries are identical except for the constant term, which was assumed to reflect sector-invariant, country-specific factors. Although we have no prior information that leads us to believe that the impact of the homemarket variable on comparative advantage differs substantially across countries, this possibility cannot be excluded a priori. To account for this possibility we have included a test of the restriction that $a_{1}=a_{2}=. .=a_{n}=a$. The results (table 4) are ambiguous. In no case can the hypothesis of a common coefficient $a$ for all countries be rejected at the $1 \%$ level. However, for 1965 and 1973 - but not for 1987 - the tests indicate that the hypothesis of a common coefficient can be rejected if the weaker criterion of a $5 \%$ significance level is adopted.

Table 5 lists the unrestricted estimates for the coefficient $a$. The results suggest that the countries of our sample may be divided roughly in four groups, depending on the strength of the relationship. For 5 countries (Japan, Denmark, Finland, Norway and Switzerland) the estimates of the coefficient $a$ are positive, significant at the $1 \%$ level, for all three years. Clearly, for these countries there is strong support for the hypothesis of a positive relationship between the two indexes. Then follows a group of 7 countries where there is some support, although weaker (positive, significant at the $10 \%$ level, for at least two years): Canada, the USA, Germany, Italy, the Netherlands, Spain and Sweden. For Belgium and Austria too, a positive relationship was reported, though significant for one year only (at the 5\% and $10 \%$ level, respectively). However, for France and the UK, the results give no support at all for the hypothesis of a positive relationship between the two indexes. Taking this information into account, we repeated the test of the restriction (a common value of $a$ for all countries) on a sample that excluded Austria, France and the UK. For this sample it was not possible to reject the restriction for any year (table 4).

The fact that the hypothesis is not empirically supported for some countries deserves an explanation. First, it cannot be excluded that this - to some extent at least - is the result of imperfect data or methods. It can be shown that there is a positive relationship between the statistical significance of the estimate $a$ and the variance of the dependent variable, i.e. that countries with a "flat" structure of export specialization (low variance) generally have poor

the implicit weight is 0.10 for $\mathrm{S}_{\mathrm{ik} 73}$ and 0.39 for $\mathrm{S}_{\mathrm{ik} 87}$. 
results. Low variance is a common problem in small samples, and it is possible that the results would have improved if the number "pairs" included in the test had been larger. This was not possible with the available data. The problem of a "flat" structure of export specialization was especially pronounced for Belgium and France, and it is possible that the poor results for these countries may be explained by data limitations. This explanation is less probable for the UK and Austria, where the reported variances do not differ much from that of the sample as a whole. Unfortunately, we do not have a good alternative explanation to offer. In general, the reported results show no clear relation to variables commonly used in cross-country analyses of specialization patterns, such as - for instance - country size or income level (past or present). Arguably, a much more detailed analysis of economic, institutional and cultural factors seems to be required. $^{13}$

The possibility of differences across home markets - in their impact on the competitiveness of suppliers - is perhaps more interesting. At least, here we have a well argued case (Porter, 1990) for assuming that home markets exposed to international competition are more conducive than others in fostering internationally competitive suppliers. This can be tested in a similar way as for the differences across countries. The results (table 6) indicate that there may be significant differences between different types of home markets. Generally speaking, the relationship between the two indexes appears to be much stronger for home-market sectors exposed to international competition (traditional manufacturing, production of transport equipment and shipping) than for the more "sheltered" sectors (agriculture and public sector services). For public sector services the results may be affected by the problem of finding reliable indicators. Still, the results lend clear support to Porter's view on the importance of competition.

The results reported in this paper may to some extent be compared with those reported by Andersen et al. (1981), although differences in both sample and methods exist. ${ }^{14}$ In particular, it must be kept in mind that their sample was much smaller. Results for 1954, 1960, 1966 and 1972 were reported. In general, a significant relationship was found for approximately one half of the countries included in their sample. The countries for which they found no support for the hypothesis, were Belgium, France, and the United Kingdom (Austria was not included). This is in line with the results presented here. Furthermore, as in the present study, there was no sign of a weakening of the relationship: in fact, the best results were reported for the most recent years.

${ }^{13}$ See Tylecote (1993) for an interesting attempt to explain cross-country differences in the degree of inter-firm collaboration with the help of some of these factors.

${ }^{14}$ See Fagerberg (1992a) for a more detailed presentation and discussion of the contribution by Andersen et al. (1981). 


\section{Concluding remarks}

The view that the home market may have a positive impact on the competitiveness of domestic producers is by no means a new one. Indeed, it has been widely held for at least a century, although neoclassical trade theorists have condemned it as "theoretically unsound". Often it has been regarded as a pure cover for protectionism. More recently, however, Michael Porter (1990) has made a major effort to increase the credibility of this view, and with considerable success, especially among policy makers and industrialists.

This paper has attempted to give an appraisal of the theoretical and empirical evidence on the hypothesis of a positive impact of the domestic market, through "advanced domestic users", on the international competitiveness of a country (the "Linder-Porter hypothesis"). It was suggested that a positive impact of this kind may be explained by a theory that focuses on interaction between users and producers of technology as a major impetus to technological change. Interaction, however, involves costs. It was argued that these are a decreasing function of both the stability of the user-producer relationship and the degree of "proximity", defined to include factors such as language, the legal system, the education system etc. Hence, most stable userproducer relationships are of a national character. The above, together with the assumption that a country's comparative advantage in the long run will be in areas where its rates of learning and innovation are high (compared to other countries), suggests that countries in the long run tend to develop comparative advantages in areas where, by a comparative standard, there are many advanced domestic users.

Most previous empirical work in this area is of a descriptive character. This paper, in contrast, has presented an econometric test of the hypothesis of a positive impact of advanced domestic users on competitiveness. The data set included 16 countries, 23 pairs of products and three selected years (1965, 1973 and 1987). The main empirical findings were:

1) There is strong support in the data for the hypothesis of a positive impact of advanced domestic users on competitiveness.

2) There is no evidence of a weakening of this relationship during the period 1965-1987.

3) The time-lag between the initial stimulus (from the domestic market) and the impact on competitiveness appears to be relatively short.

4) For most countries there is some support for the hypothesis. The most notable 
exceptions are France and the UK.

5) The relationship appears to be stronger in cases where the home-market is exposed to international competition.

In general, these findings are consistent with the predictions made by Linder (1961) and Porter (1990).

The theoretical and empirical evidence presented in this paper indicates that stable relationships between domestic users and producers of technology may have a positive impact on both technological progress and international competitiveness. This is especially so if these relationships develop in a competitive environment, i.e. that the positions of both users and producers may be contested. Thus, contrary to the belief of many economists, this approach does not favour protectionism. However, the emphasis in this approach on a competitive environment does not necessarily imply that every individual contract has to be open to public tender. Arguably, a competition policy of this kind would in practice make stable user-producer relationships very difficult to maintain. Thus, the old Schumpeterian theme of the uneasy balance between static and dynamic efficiency may apply also in this case. 


\section{References}

Arrow, K.(1962) The Economic Implications of Learning by Doing, Review of Economic Studies, vol. 29, pp. 155-73

Andersen, E.S., B. Dalum and G. Villumsen (1981) International Specialization and the Home Market, Aalborg University Press, Aalborg

Balassa, B. (1965) Trade Liberalization and 'Revealed' Comparative Advantage, The Manchester School, vol. 33, pp. 99-123

Dahmén, E. (1970) Entrepreneurial Activity and the Development of Swedish Industry 19191939, American Economic Association Translation Series, Homewood

Dosi, G. and L. Soete (1988) Technical change and international trade, in Dosi, G. et al. (eds) Technical Change and Economic Theory, Pinter, London

Fagerberg, J. (1992a) The "Home-Market Hypothesis" Reexamined, in Lundvall, B.Å. (ed) National Systems of Innovation - Towards a Theory of Innovation and Interactive Learning, Pinter, London

Fagerberg, J. (1992b) Domestic Demand, Learning and Comparative Advantage, NUPI Notat No. 475, Norwegian Institute for International Affairs, Oslo

Hirschman, A. O. (1958) The Strategy of Economic Development, Yale University Press, New Haven, Conn.

Johnston, J. (1984) Econometric Methods, McGraw-Hill, New York

Kaldor, N. and J.A. Mirrlees (1962) A New Model of Economic Growth, Review of Economic

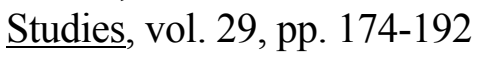

Linder, S. Burenstam (1961) An Essay on Trade and Transformation, Almquist \& Wicksell, Uppsala

List, F. (1841) Das Nationale System der Politischen Ökonomie, J. G. Cotta, Stuttgart/Tübingen

Lundvall, B. Å. (1985) Product Innovation and User-Producer Interaction, Aalborg University Press, Aalborg

Lundvall, B. Å. (1988) Innovation as an Interactive Process - from User-Producer Interaction to the National System of Innovation, in Dosi, G. et al. (eds) Technical Change and Economic Theory, Pinter, London

Perroux, F. (1956) Note sur la notion de pôle de croissance, Economie Appliquée, vol. 7, pp. $307-20$

Porter, M. E. (1990) The Competitive Advantage of Nations, MacMillan, London 
Romer, P.M. (1986) Increasing Returns and Long-Run Growth, Journal of Political Economy, vol. 94, pp. 1002-37

Tylecote, A. (1993) Managerial objectives and technological collaboration in national systems of innovation: the role of national variations in cultures and structures, CRITEC Discussion Paper No. 2, Sheffield University Management School, Sheffield

Verspagen, B. (1992) Endogenous Innovation in Neo-Classical Growth Models: A Survey, Journal of Macroeconomics, vol. 14, pp. 631-62 


\section{Appendix 1}

The trade data used in this paper were calculated from OECD Trade Series C (value data) using the IKE database on trade statistics at the Aalborg University Centre. Data for health care were taken from OECD: Health Care Systems in Transition, OECD, Paris, 1990, data for merchant fleets and telephone lines were taken from UN Statistical Yearbook, various editions. Other data from OECD National Accounts.

Construction of home-market indicators

\section{$\underline{\text { Tele and Health }}$}

$T_{j}=$ Telephone lines in country $j(i=1, \ldots, j, \ldots, n)$

$\mathrm{N}_{\mathrm{j}}=$ Number of inhabitants in $\mathrm{j}$

The index may then be written:

$$
I_{j}=\frac{T_{j}}{N_{j}} / \frac{\sum_{i} T_{i}}{\sum_{i} N_{i}}
$$

Similarly for health services, where $T_{j}=$ total (public and private) expenses for health services in current prices in common currency.

\section{$\underline{\text { Shipping }}$}

$S_{j}=$ Merchant fleet registered in country $\mathrm{j}$, in 1000 tons

$\mathrm{X}_{\mathrm{j}}=$ Total exports of goods and services from country $\mathrm{j}$ in current prices in common currency.

$$
I_{j}=\frac{S_{j}}{\sum_{i} S_{i}} / \frac{X_{j}}{\sum_{i} X_{i}}
$$


TABLE 1 EXPORT PRODUCTS AND HOME MARKET SECTORS

A) Home market: Agriculture

\begin{tabular}{|l|l|l|l|}
\hline SITC (REV 1) & EXPORT PRODUCT & SITC (REV 1) & HOME MARKET SECTOR \\
\hline 6951 & $\begin{array}{l}\text { HAND-TOOLS FOR } \\
\text { AGRICULTURE AND FORESTRY }\end{array}$ & $\begin{array}{l}04-08(-0814), \\
24\end{array}$ & $\begin{array}{l}\text { AGRICULTURAL PRODUCTS, } \\
\text { WOOD PRODUCTS }\end{array}$ \\
\hline 7121 & $\begin{array}{l}\text { AGR. MACHINERY FOR } \\
\text { PREPARING SOIL AND } \\
\text { HARVESTING }\end{array}$ & $04-08(-0814)$ & AGRICULTURAL PRODUCTS \\
\hline 7123 & MILKING MACHINES & 02 & \\
\hline 7125 & TRACTORS & $04-08(-0814)$ & AGRICULTURAL PRODUCTS \\
\hline 7129 & AGR. MACHINERY N.E.S & $04-08(-0814)$ & AGRICULTURAL PRODUCTS \\
\hline 7183 & $\begin{array}{l}\text { FOOD PROCESSING } \\
\text { MACHINERY }\end{array}$ & $0-(00)$ & FOOD \\
\hline 7191 & $\begin{array}{l}\text { HEATING AND COOLING } \\
\text { EQUIPMENT }\end{array}$ & $01-03$ & $\begin{array}{l}\text { MEAT, DIARY PRODUCTS, FISH } \\
\text { AND EGGS }\end{array}$ \\
\hline
\end{tabular}

B) Home market: Producers of traditional manufactures

\begin{tabular}{|l|l|l|l|}
\hline SITC (REV 1) & EXPORT PRODUCT & SITC (REV 1) & HOME MARKET SECTOR \\
\hline 7151 & MACHINE TOOLS FOR & 69 & METAL MANUFACTURES \\
7152 & WORKING METALS & & TEXTILES \\
\hline 7171 & TEXTILE MACHINERY & 65 & LEATHER \\
\hline 7172 & LEATHER MACHINER & 61 & CLOTHING \\
\hline 7173 & SEWING MACHINERY & 84 & $\begin{array}{l}\text { PULP AND PAPER, PAPER } \\
\text { PRODUCTS }\end{array}$ \\
\hline 7181 & PAPER WORKING MACHINERY & 25,64 & PRINTED MATTER \\
\hline 7182 & & & CRUDE MINERALS AND METALS \\
7185 & PRINTING MACHNIERY & 829 & \\
\hline & CONSTRUCTION AND MINING & 27,28 & \\
\hline
\end{tabular}

C) Home market: Producers of transport equipment

\begin{tabular}{|l|l|l|l|}
\hline SITC (REV 1) & EXPORT PRODUCT & SITC (REV 1) & HOME MARKET SECTOR \\
\hline 6291 & RUBBER TYRES AND TUBES & $732-734$ & ROAD MOTOR VEHICLES \\
\hline 7114 & AIRCRAFT ENGINES & 734 & AIRCRAFT \\
\hline 7115 & INTERNAL COMB, ENGINES & 732 & ROAD MOTOR VEHICLES \\
\hline 7294 & $\begin{array}{l}\text { AUTOMOTIVE ELECTRICAL } \\
\text { EQUIPMENT }\end{array}$ & 732 & ROAD MOTOR VEHICLES \\
\hline
\end{tabular}

D) Home market: Shipping

\begin{tabular}{|l|l|l|l|}
\hline SITC (REV 1) & EXPORT PRODUCT & SITC (REV 1) & HOME MARKET SECTOR \\
\hline 735 & SHIPS AND BOATS & & SHIPPING $^{(1)}$ \\
\hline
\end{tabular}

E) Home market: (Public sector) services

\begin{tabular}{|l|l|l|l|}
\hline SITC (REV 1) & EXPORT PRODUCT & SITC (REV 1) & HOME MARKET SECTOR \\
\hline 54 & PHARMACEUTICALS & & HEALTH $^{(1)}$ \\
\hline 7249 & TELECOMMUNICATIONS & & TELE $^{(1)}$ \\
\hline 726 & ELECTROMEDICALS & & HEALTH $^{(1)}$ \\
\hline 8617 & $\begin{array}{l}\text { MEDICAL INSTRUMENTS } \\
\text { N.E.S }\end{array}$ & & TELE $^{(1)}$ \\
\hline
\end{tabular}

(1) For the definition of this indicator, see the text and appendix 1. 


\section{TABLE 2 THE HYPOTHESIS TESTED}

1965

$$
\begin{aligned}
& 2.1 S_{i j}=-0.37+0.43 S_{i k} \quad R^{2}=0.15(0.15) \\
& (7.54)(8.14) \quad \mathrm{SER}=0.90 \\
& 2.2 S_{i j}=C_{i}+0.43 S_{i k} \\
& \text { (9.00) } \\
& R^{2}=0.39(0.36) \\
& \mathrm{SER}=0.78
\end{aligned}
$$

1973

$$
\begin{aligned}
& 2.3 \mathrm{~S}_{i j}=-0.26+0.47 \mathrm{~S}_{i k} \quad \mathrm{R}^{2}=0.17(0.17) \\
& (5.69)(8.62) \quad \mathrm{SER}=0.85 \\
& 2.4 \mathrm{~S}_{i j}=\mathrm{C}_{i}+0.49 \mathrm{~S}_{i k} \\
& \text { (9.58) } \\
& R^{2}=0.36(0.33) \\
& \mathrm{SER}=0.76
\end{aligned}
$$

1987

$$
\begin{aligned}
& 2.5 \mathrm{~S}_{i j}=-0.21+0.45 \mathrm{~S}_{\mathrm{ik}} \quad \mathrm{R}^{2}=0.15(0.15) \\
& (4.76)(8.15) \quad \mathrm{SER}=0.81 \\
& 2.6 \mathrm{~S}_{i j}=\mathrm{C}_{i}+0.49 \mathrm{~S}_{i k} \\
& R^{2}=0.33(0.30) \\
& \text { (9.19) } \\
& \mathrm{SER}=0.74
\end{aligned}
$$

$\mathrm{N}=368$

Method of estimation: Ordinary least squares, absolute t-values in brackets. $\mathrm{R}^{2}$ in brackets is adjusted for degrees of freedom. One star denotes significance at a 1\% level. 
TABLE 3. TESTING FOR LAGS (1987)

$$
\begin{aligned}
& 3.1 \mathrm{~S}_{i j 87}=\mathrm{C}_{i}+0.39 \mathrm{~S}_{i k 65} \quad \mathrm{R}_{2}=0.31(0.28) \\
& (8.46) \quad \mathrm{SER}=0.75 \\
& 3.2 S_{i j 87}=C_{i}+0.50 S_{i k 65}+0.34\left(S_{i k 87}-S_{i k 65}\right) \\
& (9.37) \quad(3.85) \\
& \text { * } \\
& R^{2}=0.34(0.30) \\
& \mathrm{SER}=0.74 \\
& 3.3 S_{i j 87}=C_{i}+0.43 S_{i k 73} \quad R^{2}=0.31(0.28) \\
& \text { (8.64) } \quad \mathrm{SER}=0.75 \\
& \begin{aligned}
3.4 S_{i j 87}=C_{i}+\underset{(9.20)}{0.49} S_{i k 73}+0.39\left(S_{i k 87}-S_{i k 73}\right) & (2.97)
\end{aligned} \\
& \star \quad * \\
& R^{2}=0.33(0.30) \\
& \mathrm{SER}=0.74 \\
& \mathrm{~N}=368
\end{aligned}
$$

Method of estimation: Ordinary least squares, absolute t-values in brackets. $R^{2}$ in brackets is adjusted for degrees of freedom. One star denotes significance at a $1 \%$ level. 
TABLE 4 TESTING FOR POOLING

$\underline{1965} \quad \underline{1973} \quad \underline{1987}$

16 country sample $e^{1)}$

$2.03 \quad 1.98 \quad 1.58$

13 country sample $e^{2)} \quad 1.53 \quad 1.44 \quad 1.59$

1)All countries, F-statistics with degrees of freedom 15,336.

2)All countries less Austria, France and UK, F-statistics with degrees of freedom 12,273.

* Significance of test, 1\% level.

** Significance of test, 5\% level. 
TABLE 5 Unrestricted estimates for $S_{i k}{ }^{1)}$

\begin{tabular}{|c|c|c|c|}
\hline & 1965 & 1973 & 1987 \\
\hline Canada & $\begin{array}{c}0.28 \\
(1.52) \\
\star \star \star\end{array}$ & $\begin{array}{c}0.20 \\
(1.01)\end{array}$ & $\begin{array}{c}0.42 \\
(2.15) \\
\star \star\end{array}$ \\
\hline USA & $\begin{array}{c}0.43 \\
(1.38) \\
\star \star \star\end{array}$ & $\begin{array}{c}0.37 \\
(1.78) \\
\star \star\end{array}$ & $\begin{array}{c}0.38 \\
(1.49) \\
\star \star \star\end{array}$ \\
\hline Japan & $\begin{array}{c}0.78 \\
(4.08) \\
\star\end{array}$ & $\begin{array}{c}0.78 \\
(4.18) \\
\star\end{array}$ & $\begin{array}{c}0.51 \\
(3.38) \\
\star\end{array}$ \\
\hline Austria & $\begin{array}{c}0.26 \\
(1.45) \\
\star \star \star\end{array}$ & $\begin{array}{c}0.11 \\
(0.59)\end{array}$ & $\begin{array}{c}0.16 \\
(0.79)\end{array}$ \\
\hline Belgium & $\begin{array}{c}0.13 \\
(0.35)\end{array}$ & $\begin{array}{c}0.14 \\
(0.45)\end{array}$ & $\begin{array}{c}0.43 \\
(1.76) \\
\star \star\end{array}$ \\
\hline Denmark & $\begin{array}{c}0.58 \\
(3.95) \\
\star\end{array}$ & $\begin{array}{c}0.56 \\
(3.72) \\
\star\end{array}$ & $\begin{array}{c}0.77 \\
(4.78) \\
*\end{array}$ \\
\hline Finland & $\begin{array}{c}0.50 \\
(3.69) \\
\star\end{array}$ & $\begin{array}{c}0.47 \\
(2.93) \\
\star\end{array}$ & $\begin{array}{c}0.51 \\
(2.78) \\
\star\end{array}$ \\
\hline France & $\begin{array}{l}-0.20 \\
(0.43)\end{array}$ & $\begin{array}{c}-0.09 \\
(0.45)\end{array}$ & $\begin{array}{l}-0.09 \\
(0.02)\end{array}$ \\
\hline Germany & $\begin{array}{c}0.31 \\
(1.34) \\
\star \star \star\end{array}$ & $\begin{array}{c}0.42 \\
(1.50) \\
\star \star \star\end{array}$ & $\begin{array}{c}0.31 \\
(0.80)\end{array}$ \\
\hline Italy & $\begin{array}{c}0.19 \\
(0.69)\end{array}$ & $\begin{array}{c}0.41 \\
(1.46) \\
\star \star \star\end{array}$ & $\begin{array}{c}0.54 \\
(2.15) \\
\star \star\end{array}$ \\
\hline Netherlands & $\begin{array}{c}0.10 \\
(0.43)\end{array}$ & $\begin{array}{c}0.32 \\
(1.37) \\
\star \star \star\end{array}$ & $\begin{array}{c}0.36 \\
(1.74) \\
\star \star\end{array}$ \\
\hline Norway & $\begin{array}{c}0.42 \\
(3.03) \\
\star\end{array}$ & $\begin{array}{c}0.57 \\
(3.85) \\
\star\end{array}$ & $\begin{array}{c}0.60 \\
(3.73) \\
\star\end{array}$ \\
\hline Spain & $\begin{array}{c}0.33 \\
(2.61) \\
\star\end{array}$ & $\begin{array}{c}0.39 \\
(2.21) \\
\star \star\end{array}$ & $\begin{array}{c}0.23 \\
(1.09)\end{array}$ \\
\hline Sweden & $\begin{array}{c}1.00 \\
(5.13) \\
\star\end{array}$ & $\begin{array}{c}0.47 \\
(2.08) \\
\star \star\end{array}$ & $\begin{array}{c}0.10 \\
(0.50)\end{array}$ \\
\hline Switzerland & $\begin{array}{c}0.78 \\
(4.16) \\
\star\end{array}$ & $\begin{array}{c}0.92 \\
(5.45) \\
\star\end{array}$ & $\begin{array}{c}1.12 \\
(5.77) \\
\star\end{array}$ \\
\hline UK & $\begin{array}{c}-0.16 \\
(0.66)\end{array}$ & $\begin{array}{c}-0.17 \\
(0.60)\end{array}$ & $\begin{array}{c}0.40 \\
(0.78)\end{array}$ \\
\hline
\end{tabular}


1) Estimated with country dummies $\left(C_{i}\right)$.

Method of estimation: Ordinary Least Squares, absolute-t values in brackets. * = Significant, $1 \%$ level, one-tailed test.

** = Significant, 5\% level, one-tailed test.

$* * *=$ Significant, $10 \%$ level, one-tailed test. 


\section{Table 6/ Testing for differences between home market sectors ${ }^{1}$}

\section{7}

$$
\begin{aligned}
& C_{i}+0.23 S_{i k}^{\text {agriculture }}+0.52 S_{i k}^{\text {traditonal }} \\
& \text { (2.74) (5.74) } \\
& S_{i j}=+\begin{array}{c}
0.68 S_{i k}^{\text {transport }}+0.89 S_{i k}^{\text {shipping }} \\
(6.59)
\end{array} \\
& +0.55 S_{i k}^{\text {public }} \\
& \text { (1.67) } \\
& R^{2}=0.36(0.32) \\
& S E R=0.72 \\
& N=368 \\
& F_{(5,347)}=3.89
\end{aligned}
$$

$(*)$

1) Method of estimation: Ordinary least squares, absolute tvalues in brackets. $\mathrm{R}^{2}$ in brackets is adjusted for degrees of freedom. $F_{(5,347)}$ is a F-test of whether there are significant differences across home-market sectors. One star denotes significance of test at a 1\% level. 